\title{
Arsenic Removal with Iron(II) and Iron(III) in Waters with High Silicate and Phosphate Concentrations
}

Linda C. Roberts ${ }^{1}$, Stephan J. Hug ${ }^{1 *}$, Thomas Ruettimann ${ }^{1}$, Md Morsaline Billah ${ }^{2}$ Abdul Wahab Khan ${ }^{2}$ and Mohammad Tariqur Rahman ${ }^{2}$

${ }^{I}$ Swiss Federal Institute for Environmental Science and Technology (EAWAG), Überlandstrasse 133, CH-8600 Dübendorf, Switzerland

${ }^{2}$ Biotechnology and Engineering Discipline, Khulna University, Khulna 9208, Bangladesh

\section{Supporting Information}


Figures with fits calculated from fixed coefficients for the As(III) oxidation

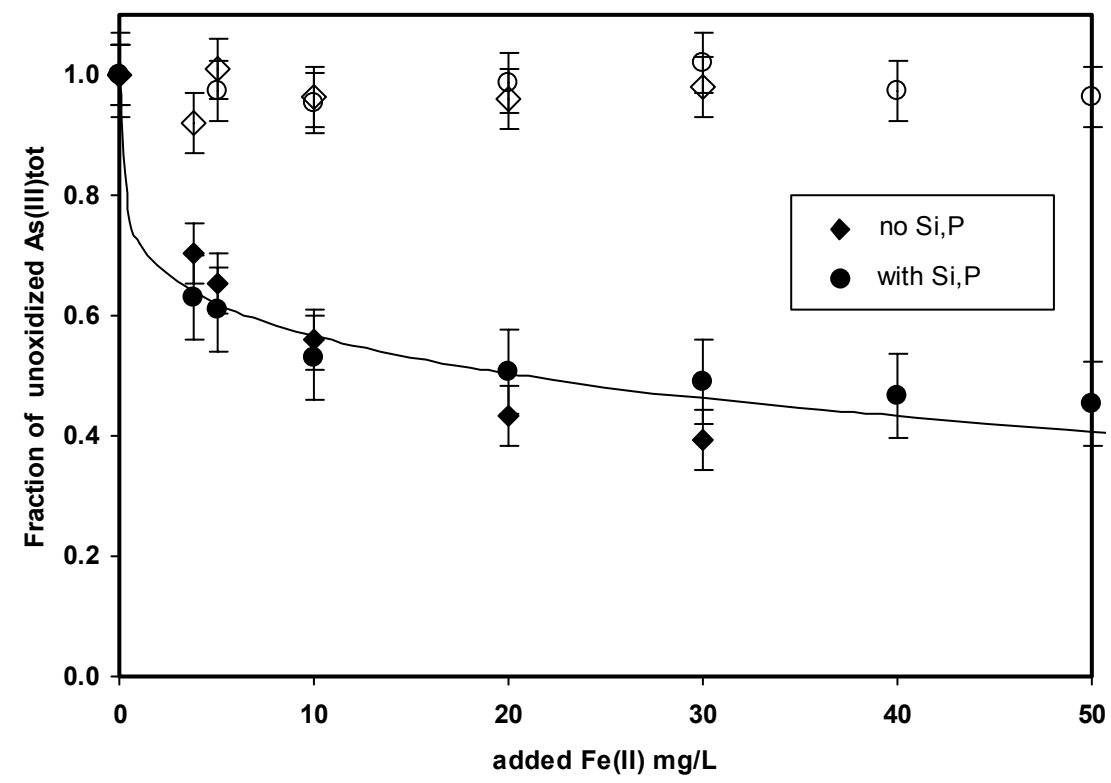

Figure S1. Oxidation of As(III) with added Fe(II) (full symbols) and with Fe(III) (empty symbols) in the presence and absence of $3.0 \mathrm{mg} / \mathrm{L} \mathrm{P}$ and $30 \mathrm{mg} / \mathrm{L} \mathrm{Si}$. The thin line is fit to the unoxided As(III) in this figure: $\left[\mathrm{As}(\mathrm{III})_{\mathrm{ox}}\right]=[\mathrm{As}(\mathrm{III})]_{0} \times 2.30 \times[\mathrm{Fe}(\mathrm{II})]_{0}^{0.193}($ with molar concentrations).

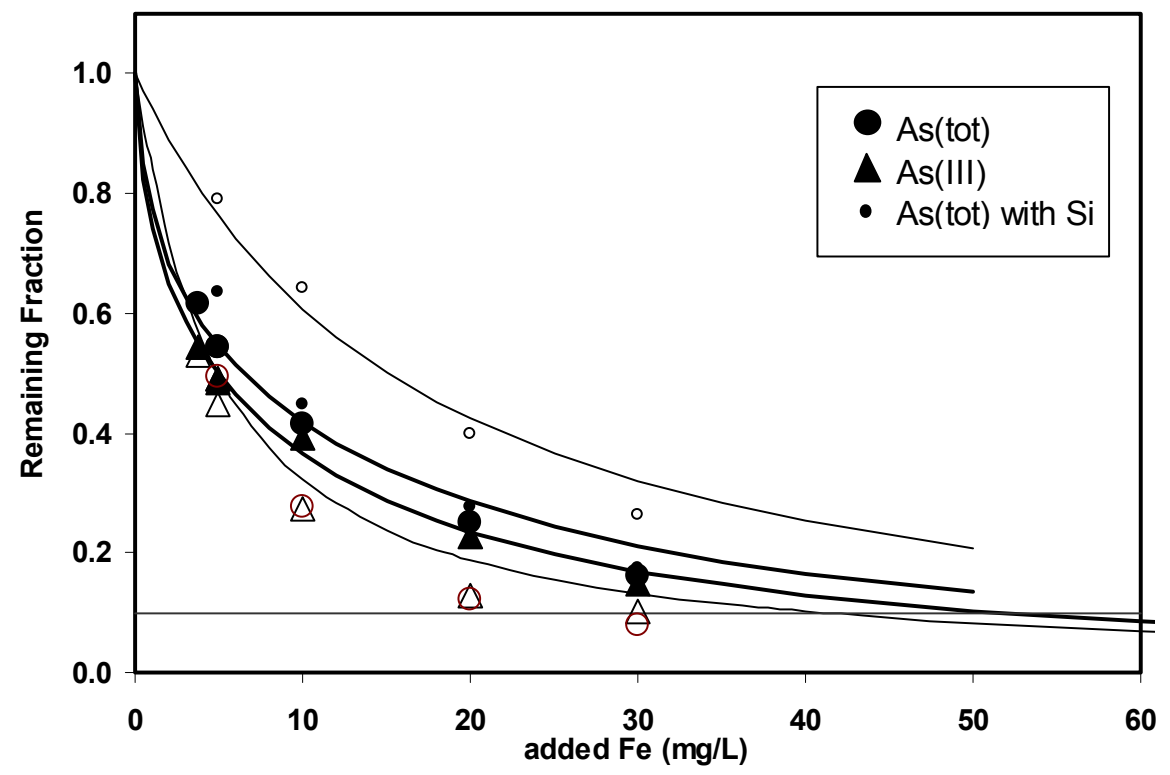

Figure S3. Removal of dissolved As(tot) and As(III) in the absence of $\mathrm{P}$ and $\mathrm{Si}$ with $\mathrm{Fe}$ (II) (full symbols and thick lines) and with Fe(III) (empty symbols and thin lines). The lines represent the output from the model calculation. The removal of As(tot) in the presence of $30 \mathrm{mg} / \mathrm{L} \mathrm{Si}$ is shown with smaller symbols and lines ending at $50 \mathrm{mg} / \mathrm{L}$. Initial concentrations: $500 \mu \mathrm{g} / \mathrm{L} \mathrm{As}(\mathrm{III})$. 


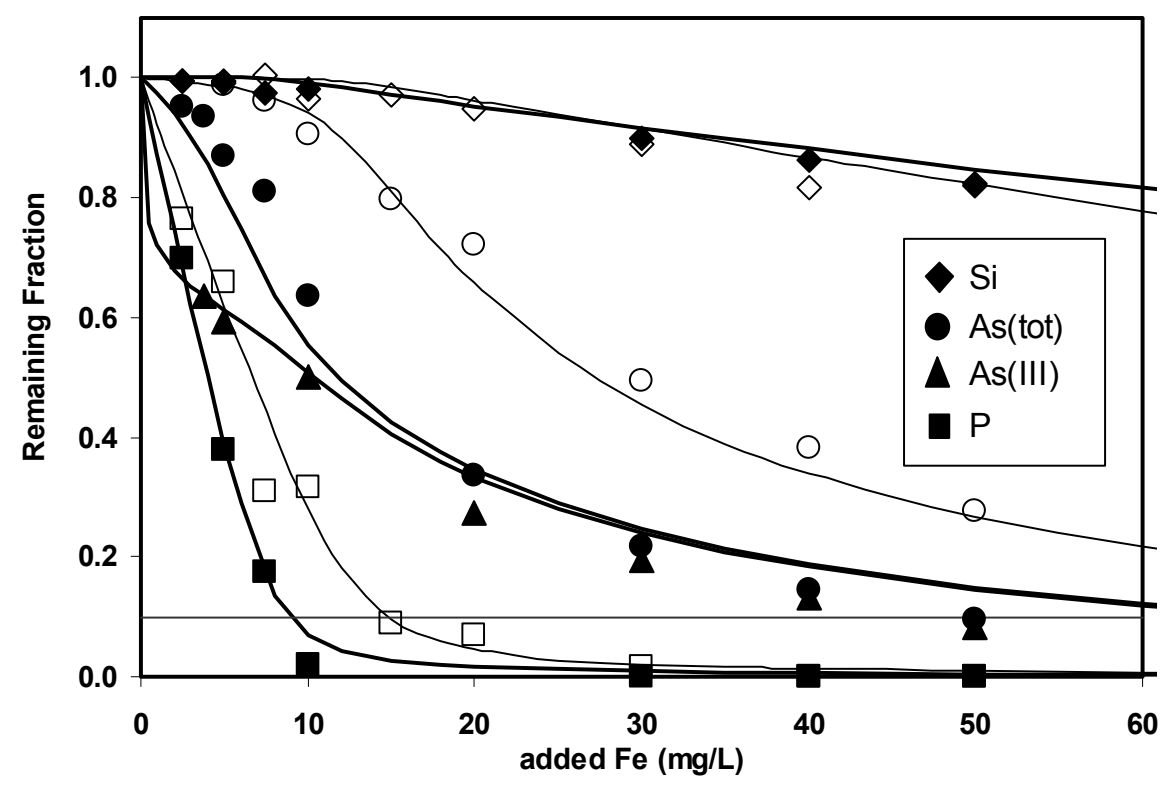

Figure S5. Removal of dissolved silicate, As(tot), As(III) and phosphate with added Fe(II) (full symbols and thick lines) and with Fe(III) (empty symbols and thin lines). The lines represent the output from the model calculation. Initial concentrations: $500 \mu \mathrm{g} / \mathrm{L} \mathrm{As}(\mathrm{III}), 3.0 \mathrm{mg} / \mathrm{L} \mathrm{P}$ and 30 mg.

\section{Chemical coefficient matrix for the coprecipitation modeling}

\begin{tabular}{|l|l|l|l|l|l|l|}
\hline & $\equiv \mathrm{Fe}-\mathrm{OH}$ & $\mathrm{Si}$ & $\mathrm{P}$ & As3 & As5 & $\log (\mathrm{K})$ \\
\hline$\equiv \mathrm{Fe}-\mathrm{OH}$ & 1 & 0 & 0 & 0 & 0 & 0 \\
$\mathrm{Si}$ & 0 & 1 & 0 & 0 & 0 & 0 \\
$\mathrm{P}$ & 0 & 0 & 1 & 0 & 0 & 0 \\
$\mathrm{As} 3$ & 0 & 0 & 0 & 1 & 0 & 0 \\
$\mathrm{As} 5$ & 0 & 0 & 0 & 0 & 1 & 0 \\
$\equiv \mathrm{Fe}-\mathrm{Si}$ & 1 & 1 & 0 & 0 & $\mathrm{~K}_{\mathrm{Si}}$ \\
$\equiv \mathrm{Fe}-\mathrm{P}$ & 1 & 0 & 0 & 0 & 0 & $\mathrm{~K}_{\mathrm{P}}$ \\
$\equiv \mathrm{Fe}-\mathrm{As} 3$ & 1 & 0 & 0 & 1 & 0 & $\mathrm{~K}_{\mathrm{As} 3}$ \\
$\equiv \mathrm{Fe}-$ As5 & 1 & 0 & 0 & 0 & 1 & $\mathrm{~K}_{\mathrm{As} 5}$ \\
\hline total Conc & {$[\mathrm{Fe}]_{0} / \mathrm{p}(5)$} & 0 or 30mg/L & 0 or 3mg/L & As(III $)_{\text {tot }}$ & As(V) $)_{\text {tot }}$ & \\
\hline
\end{tabular}




\section{Model Input}

Known are the added (initial) concentrations:

$[\mathrm{Fe}(\mathrm{II})]_{0}$ or $[\mathrm{Fe}(\mathrm{III})]_{0}$ and $[\mathrm{As}(\mathrm{III})]_{0},[\mathrm{As}(\mathrm{V})]_{0},[\mathrm{P}]_{0}$ and $[\mathrm{Si}]_{0}$.

The concentrations that enter the equilibrium model are:

$[\equiv \mathrm{Fe}-\mathrm{OH}]_{0}$ formed from $\mathrm{Fe}(\mathrm{II})$ or $\mathrm{Fe}(\mathrm{III})$ at concentrations of $[\mathrm{Fe}(\mathrm{III})]_{0} / \mathrm{p}(5)$ or $[\mathrm{Fe}(\mathrm{II})]_{0} / \mathrm{p}(5)$,

respectively, where $\mathrm{p}(5)$ is an adjustable parameter (different for $\mathrm{Fe}(\mathrm{II})$ and $\mathrm{Fe}(\mathrm{III})$

and

$[\mathrm{As}(\mathrm{III})]_{\mathrm{tot}},[\mathrm{As}(\mathrm{V})]_{\mathrm{tot}},[\mathrm{P}]_{\mathrm{tot}}$ and $[\mathrm{Si}]_{\mathrm{tot}}$.

$[\mathrm{P}]_{\text {tot }}$ and $[\mathrm{Si}]_{\text {tot }}$ are equal to $[\mathrm{P}]_{0}$ and $[\mathrm{Si}]_{0}$;

However, $[\mathrm{As}(\mathrm{III})]_{\text {tot }}$ and $[\mathrm{As}(\mathrm{V})]_{\text {tot }}$ are not equal to $[\mathrm{As}(\mathrm{III})]_{0},[\mathrm{As}(\mathrm{V})]_{0}$ when Fe(II) is added, as $\mathrm{As}(\mathrm{III})$ is partly oxidized during the oxidation of $\mathrm{Fe}(\mathrm{II})$ :

$$
\begin{aligned}
& {[\operatorname{As}(\mathrm{III})]_{\mathrm{tot}}=[\mathrm{As}(\mathrm{III})]_{0}-\left[\mathrm{As}(\mathrm{III})_{\mathrm{ox}}\right]} \\
& {[\operatorname{As}(\mathrm{V})]_{\mathrm{tot}}=[\mathrm{As}(\mathrm{V})]_{0}+\left[\mathrm{As}(\mathrm{III})_{\mathrm{ox}}\right]} \\
& {\left[\operatorname{As}(\mathrm{III})_{\mathrm{ox}}\right]=[\mathrm{As}(\mathrm{III})]_{0} * \mathrm{p}(6) *[\mathrm{Fe}(\mathrm{II})]_{0}^{\mathrm{p}(7)}} \\
& {[\operatorname{As}(\mathrm{tot})]_{\mathrm{d}}=[\mathrm{As}(\mathrm{III})]_{\mathrm{d}}+[\mathrm{As}(\mathrm{V})]_{\mathrm{d}}}
\end{aligned}
$$

\section{Fitting of the adjustable parameters:}

The sum of squared differences, normalized to initial concentrations, was expressed as:

$$
\begin{aligned}
\mathrm{SSD}=\Sigma & {\left[\left([\mathrm{As}(\text { tot })]_{\mathrm{d} \exp }-[\mathrm{As}(\text { tot })]_{\mathrm{d} \bmod }\right)^{2} /[\mathrm{As}(\text { tot })]_{0}^{2}\right.} \\
+ & \left([\mathrm{As}(\mathrm{III})]_{\mathrm{d} \exp }-[\mathrm{As}(\mathrm{III})]_{\mathrm{d} \bmod }\right)^{2} /[\mathrm{As}(\mathrm{III})]_{0}^{2} \\
+ & \left([\mathrm{P}]_{\mathrm{d} \exp }-[\mathrm{P}]_{\mathrm{d} \bmod }\right)^{2} /[\mathrm{P}]_{0}^{2} \\
+ & \left.\left([\mathrm{Si}]_{\mathrm{d} \exp }-[\mathrm{Si}]_{\mathrm{d} \bmod }\right)^{2} /[\mathrm{Si}]_{0}^{2}\right]
\end{aligned}
$$

where the sum is over all experiments with $\mathrm{Fe}(\mathrm{II})$ or $\mathrm{Fe}(\mathrm{III})$ additions, respectively. 
The data for the fitting (Figures 2-5) consisted of 32 experiments and 84 data points for Fe(II) and of 38 experiments with 91 data points for Fe(III). The parameters were well constrained. Even if both data sets were subdivided into 3 independent sets each by taking every third data point (starting from the first, second and third point) through the successive data points shown in Figures 2-5, similar optimized values were obtained. The average values and standard deviations obtained from the three fits each are shown in Table 3 in the main paper.

The following figures show that the fitting parameters are well constrained. Shown is the Sum of Squared Differences (SSD) as a function of varying each fitting parameter while keeping the other parameters at their optimized values. Fitted were all Fe(II) and Fe(III) data, respectively, shown in Figures 2-5.

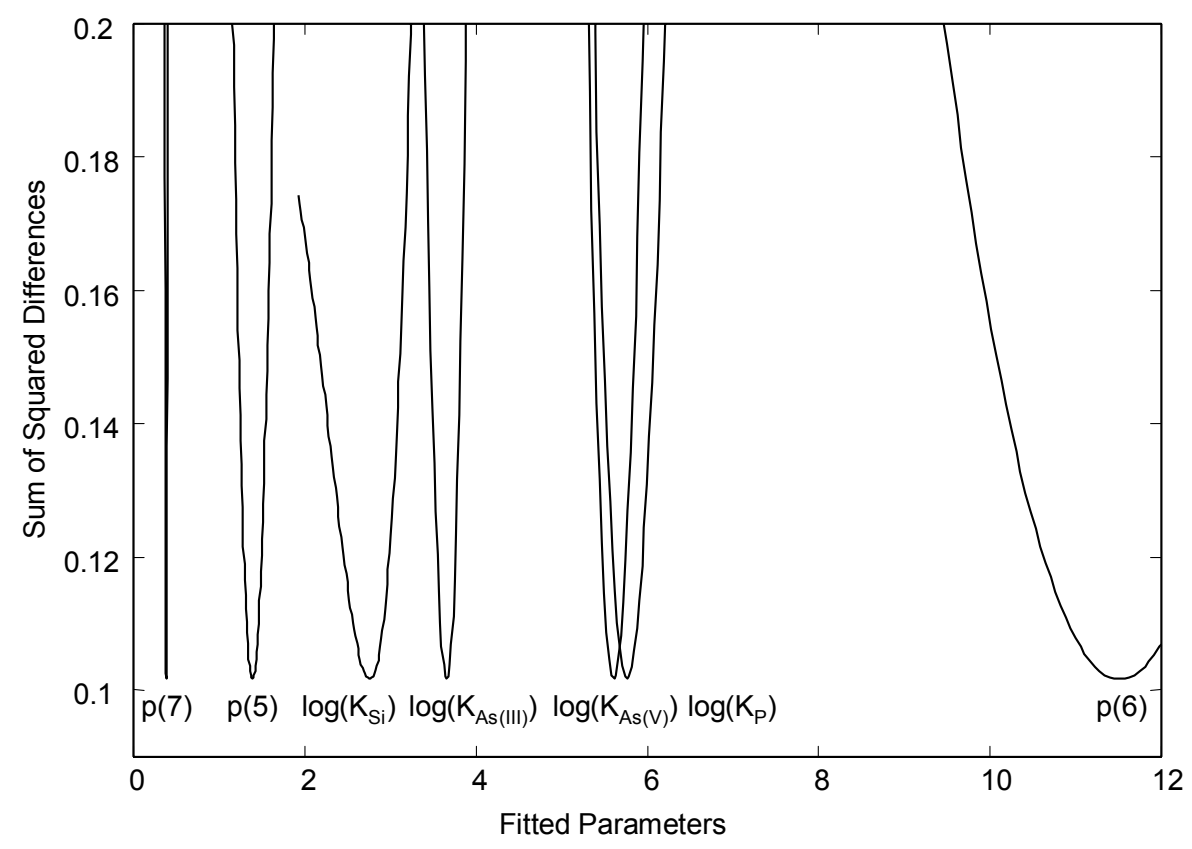

Figure S9. Fitting of the Fe(II) data. The parameters $p(6)$ and $p(7)$, which model the oxidation of $\mathrm{As}(\mathrm{III})$, are interdependent and $\mathrm{p}(6)$ is not as well constrained as the other parameters. However, the $\log (\mathrm{K})$ 's and $\mathrm{p}(5)$ are almost insensitive to $\mathrm{p}(6)$ and $\mathrm{p}(7)$ (Table 3), as long as the As(III) oxidation is expressed reasonably well with the empirical equation. 


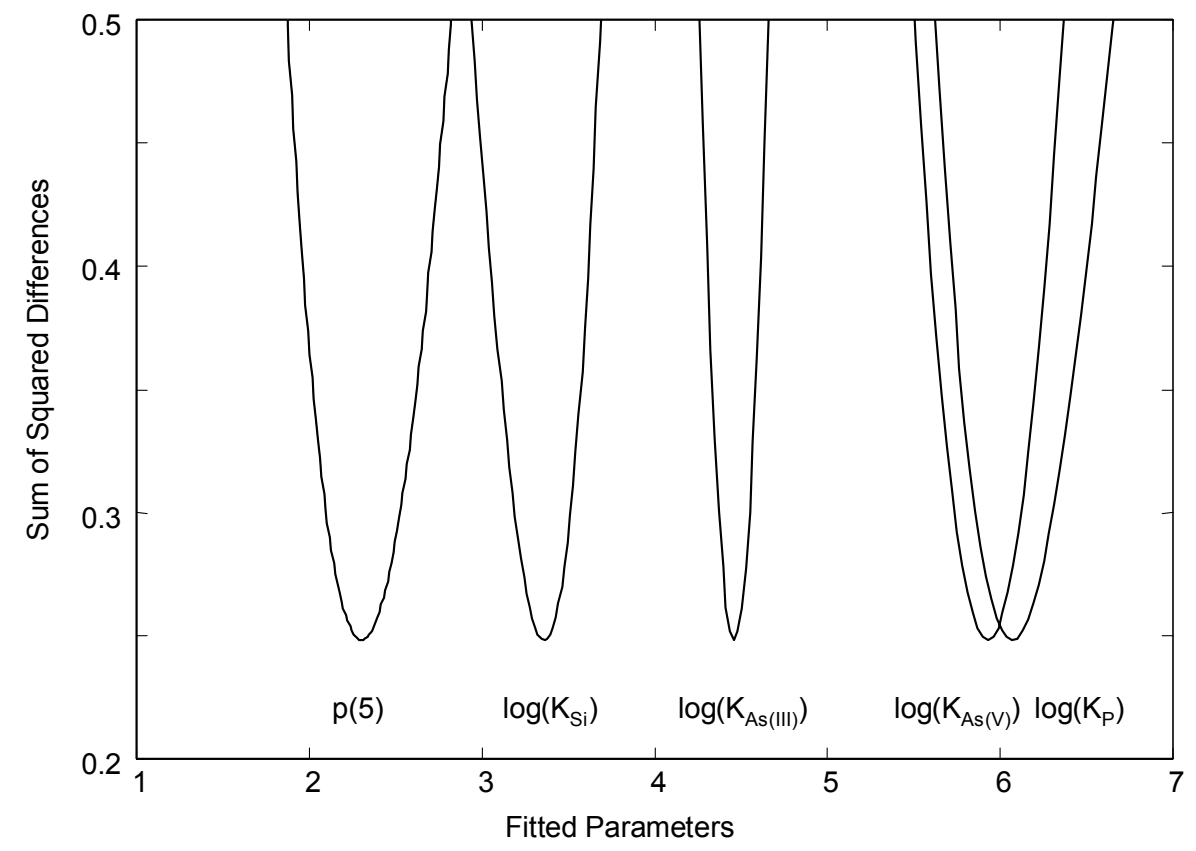

Figure S10. Fitting of the Fe(III) data. All $\log (\mathrm{K})$ 's and $\mathrm{p}(5)$ (expressing the site density) are well constrained. 